\title{
Kremlin Capitalism: Privatizing the Russian Economy, 1997, by Joseph R. Blasi, Maya Kroumova, and Douglas Kruse. foreword by Andrei Shleifer ; with the research assistance of Daria Panina. Ithaca, NY: ILR Press, xix, 249 pp.
}

\author{
Reviewed by Dr. Tatyana G. Bogomazova, Researcher, Peter the Great \\ Museum of Anthropology and Ethnography (Kunstkamera) of the \\ Russian Academy of Sciences, St. Petersburg, Russia \\ (info@kunstkamera.lanck.ru)
}

The authors of this excellent, clearly written and approachable volume evaluate the privatization process in Russia from 1991 to 1996. Privatization is presented in the broader context of Russian economic reforms that took place in the period after "perestroika." Specialists and common readers will find this book particularly valuable, whether seeking a better theoretical understanding of privatization in Russia or specific details of this most recent history.

First author Joseph Blasi served on a US Agency for International Development advisory team from Harvard University's Institute for International Development. Andrei Shleifer, author of this volume's Foreword, had a unique chance to work with Deputy Prime Minister Anatoly Chubais--the cabinet minister responsible for privatization--and his deputy, Dmitry Vasilev. From this lofty vantage point, Blasi and his colleagues were allowed to observe policy making around the process of privatization. Their appointments also provided an unusual opportunity to form a research program analyzing the transition process. Maya Kroumova and Douglas Kruse helped with the analysis of the evidence. The result is a very important documentary source for economists and decision makers.

At the outset, useful background information is presented concerning the political and economic context of the postcommunist period. A "Chronology of Major Events" is presented to help render more coherent the whirlwind of history. The introductory chapter follows, and it is of particular value for its assessment of the reasons of privatization, its program, and how it worked. Here one can find interesting details lifting the veil that masked the privatization backstage. A summary of "The Russian Business Economy and Companies" presents a considerable wealth of statistical data, and serves as an excellent overview to the emerging private sector.

The discussion then moves to questions specific to the period of privatizing under conditions of a newborn market system. Special chapter-length emphasis is given to discussions of "Ownership," "Power" and "Restructuring." The second chapter is dedicated to the initial division of ownership, how the struggle for it unfolded, and finally, an analysis of how property has actually been distributed to private citizens. One of the main points of the chapter concerns the attitude of Russian citizens toward voucher privatization: "The Russian public became more cynical about privatization . . ., Russians increasingly questioned privatization" (p. 76). These inferences are based on the results of 
series of surveys that allowed the authors to conclude: “. . . limits of citizen participation in the new economy were supplemented by a host of the other problems that complicated the public's perception of privatization." The authors properly point out that the share of property given to citizens must be viewed in the context of the declining living standards of many Russians.

Chapter 3 reviews the circumstances of initial transition, governance in 1996, and the status of workers as shareholders and employees. But the most interesting part of the chapter is a section entitled "The Mafia as a Corporate Power." Evidence concerning this "grey eminence" of privatization in Russia is scarce, and for obvious reasons it is difficult to substantiate folk wisdom holding that criminal elements are linked with corrupt members of the "nomenklatura" in dividing the country into spheres of influence (p. 119). But the authors are careful not to exaggerate the criminal elements' influence over the Russian economy. They assume there are three areas chiefly controlled by the Russian mob: (1) smaller privatized and start-up businesses, (2) smuggling and transportation of valuable commodities; wholesale and retail outlets where products can quickly be turned into cash, and (3) some portion of very profitable large enterprises that produce commodities or have some access to them (p. 119). The authors believe organized crime wants risk-adjusted return, so large, privatized, unprofitable firms are out of criminal control. Here I would argue with the authors, as an unprofitable weak company may cut employees, reduce capacity, and confront serious cash-flow problems, while its director actually might be one of the most affluent persons in a given region. It may be to his advantage to promote an unfavorable image of his company and appeal to the contemporary social mood of overall crisis. This is especially relevant in the post-Soviet economy, in which information concerning corruption is widely suppressed, leading to artificially low official rates.

A central point, to which the authors devote a separate chapter and return repeatedly, is restructuring. "What is true restructuring?" they ask. Their answer relies on an analysis of business operations, management and control, social services for employees, access to capital, and so forth. In other words, their analysis of the barriers to restructuring and the emergence of private capital markets focuses not only on the official planning discourse, but on real problems around real changes. The analysis is convincing, as it relies on relevant statistical data from a range of reliable sources.

The book's last chapter is devoted to the future of reforms. It sounds especially interesting now, with the old Russian government having been dismissed and our society experiencing recurrent governmental crises. From this perspective, the title of the issue "The Reality From Which There Is No Escape" is particularly intriguing. "The harsh reality is that there is no alternative to far-reaching changes in most of Russia's enterprises" - this observation seems to be the most obvious and perspicacious conclusion in the final analysis. We may just hope the current situation would be the start of a new period of reforms. That they are needed is brightly proved by Kremlin Capitalism and its authors. 